
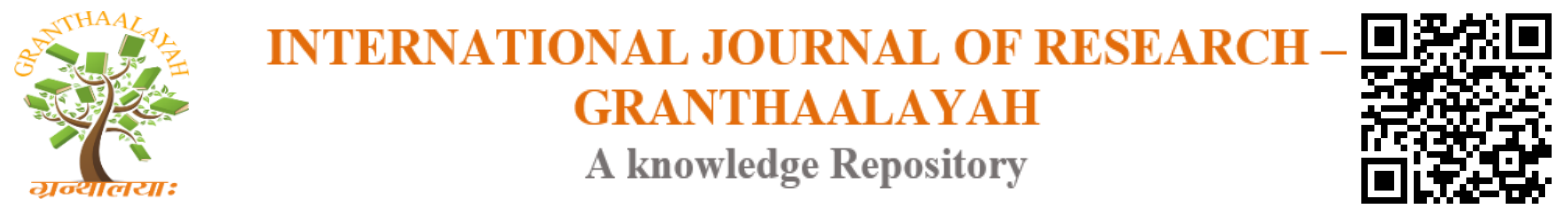

Social

\title{
NON-ALIGNED MOVEMENT IN THE GLOBAL POLITICS ERA
}

\author{
Sheveta Sehgal *1 \\ ${ }^{* 1}$ M.Phil., Ph.D., International Politics, Political Science, Mohali, Punjab, India
}

\begin{abstract}
The drastic changes in the world scene in the 1990's such as the declaration of the end of the Cold War. The Non-alignment movement had been perceived differently by the "aligned" of the East and the west. The NAM originally developed in the context of a bipolar world. In course of time other centers of power came up and used their military and economic capacities to bend the policies of newly- free or small countries to fit in with their strategies. Today even this multi polarity is less in evidence.
\end{abstract}

Keywords: Globalization; Movement; Transnational; Conferences; Politics.

Cite This Article: Sheveta Sehgal. (2019). "NON-ALIGNED MOVEMENT IN THE GLOBAL POLITICS ERA." International Journal of Research - Granthaalayah, 7(8), 507-512. https://doi.org/10.29121/granthaalayah.v7.i8.2019.705.

\section{Introduction}

Global politics represents a transnational world, containing elements of many cultures, political practices and power structures. The dramatic developments on the surface of contemporary global politics and the intensification of underlying trends such as globalization show that the world has entered a transitional era. The growing significance of international organizations, law and norms in the post-Cold War system, the rise and consequences of interdependence and liberalization in the international political economy, and the spread of capitalism and regional integration are all linked to the globalization process.

Non-Aligned Movement (NAM) can be termed as a situational movement that developed out of the anti-imperialist movement and later served as an instrument to safeguard the interests of small powers in the biopolar world and continues to serve that purpose even in the changed world scenario. India has been broadly conforming to the criteria of membership of retaining largely and essentially, its freedom of policy and action in external affairs, of declining to join alliance with any great power.

The drastic changes in the world scene in the 1990's such as the declaration of the end of the Cold War at the Malta summit between Gorbachov and Bush in 1990; disintegration of the USSR in 
December 20, 1991; disbanding of Warsaw Pact on July 1,1991; reunification of Germany on November 9-10, 1994 have led to a debate on the relevance of the NAM ${ }^{1 .}$

The Bandung conference was the most important step in the emergence of NAM; it was held in Bandung (Indonesia) from April 18 to 24, 1955. Twenty-nine countries, six from Africa and twenty-three from Asia, Participated in this conference. Leopard senghor described it as the most important event, since the renaissance, that spelled death to the inferiority complex of colonial people. ${ }^{2}$ The conference "elaborated the principles of Panchsheel into ten principles ${ }^{3}$ and provided a framework for the evolution of NAM. Bandung fore shadowed the NAM in its agenda devoted to the problem of colonialism, economic development and maintenance of peace. Later on, a meeting between Tito, Nehru and Nasser was held on the island of Brioni (Yugoslavia), in July 1956 in which the basic principle for world peace and cooperation were proposed by the three founder of non- alignment. ${ }^{4}$ The movement became truly worldwide with the Belgrade conference of non- aligned countries in 1961 at which president of Yugoslavia and Nasser of Egpt, along with the early Asian leaders, played significant roles. ${ }^{5}$

The summit declared that the consequences of nuclear war would affect the entire world, and all nations and peoples therefore had an abiding concern and interest in the avoidance of this calamity. ${ }^{6}$ The NAM originally developed in the context of a bipolar world. In course of time other centers of power came up and used their military and economic capacities to bend the policies of newly- free or small countries to fit in with their strategies. ${ }^{7}$

The emergence of non-alignment is often attributed to the Cold War context and the superpower tension emanating from it. This certainly true in the sense that the cold war was an expression of a self-contradictory situation caused by the application of the theory of power orthodoxy to qualitatively different world scene. Factors responsible for the inevitable emergence of nonalignment as a typical policy style of countries of the south, abound first of all, it emanated from humanistic socialism, in contradiction to scientific, as an ideological stance adopted by the newly -independent countries with a view to implementing various development strategies for public welfare

The NAM has for long avoided issue of conflict between its own members. This may not be possible, it will, sooner or later, feel the need of evolving a mechanism of mediation and conciliation among its members in the spirit of co- operation. For the matter, the movement should forge intimate relation with regional organization like OAU, the Arab League, the OAS, the Asean and the SAARC.

Sadly, the NAM 's attention is intermittently diverted to the useless projects such as improving methodology or improving procedures or peaceful settlement of disputes - which really are a cover for their lack of political will to improvement already existing methods/ procedures which are quite adequate as in the case of the United Nation ${ }^{8}$

The NAM was an initiative for peaceful, co-existence, decolonization and regional. Co- operation that arose third world. The notion of non- alignment of rejecting the concept of a world in which it was necessary to align oneself with one of two rival blocs- was a novel one, and often seen in its initial stages as hostile to the interests of the major power block that emerged after the second 
world war. To espouse this course at the united nations during it early gears as Nehru has observed was "to placing a lonely furrow. Despite the well-known facts of India being the pioneer of the policy of non-alignment and of being a founder member of the NAM there have been in India (as outside) for some years widespread skepticism about the continuing relevance of the NAM.

This skepticism has arisen because of the role of the vast majority of members of the NAM in legitimizing nuclear weapons (and in supporting the so-called comprehensive Test Ban Treaty (CTBT), both at the Disarmament conference and the US General Assembly. NAM has been consistently critical of nuclear weapons, and yet, those members of the NAM (with a few notable exceptions like India) have made a volteface and gone along with the nuclear weapons power in upholding the legitimacy of these weapons, and what is more forever, thereby reinforcing the traditional hegmonism of the great power over the sovereign state system. In $12^{\text {th }}$ NAM Summit, the NAM Declaration observed that the present situation in which the nuclear weapon states monopolized the right to own weapons of mass destruction was "highly discriminatory, unstable and cannot be sustained. ${ }^{9}$

It was (NAM) against hegemony, against arm-twisting by the powerful ("If you are not with us, then you are against us") and the mighty. Many critics up Indian foreign policy allege that India was not genuinely Non-Aligned and point out that while Indian leaders like Nehru, Indira Gandhi and others were critical of the United States and the Western countries, they ignored many of the misdemeanors of the Soviet Block. ${ }^{10}$ What was expected at Havana was that India along with other NAM countries would respond to the 'essential logic' of the interventionist foreign policy pursued by the American state. Prime Minister Jawaharlal Nehru and Indira Gandhi had followed the policy of Non-Alignment in the true sense of the term; the same has been as much re-emphasized upon Prime Minister Manmohan Singh when he stated that Non-Alignment is the ability to exercise an independent Judgement on all issues. The NAM was a powerful movement of 'dissent' against 'hegemonic superpower, and India was one of the leaders of such an activist approach against hegemonism.

The process of globalization has led to the free movement of people, ideas, finance, technology and this movement has cut across the limits imposed by the sovereign states. Foreign Minister of India clearly stated on 3 February 2008 that 'we are trying to open vistas of nuclear deals with France and Russia as well as US. India is a nuclear weapon power, it is a pity India is not playing for some years, especially since the end of the Cold War, the kind of role justified by its geopolitical assets and expectations by other nation too. It is time that India realizes these expectations and reasserts itself by a more positive, dynamic role, proportionate to its assets and its heritage

\section{Economic Issues}

The global economy continued to be characterized by vastly different levels of development. The globalized economy offers great opportunities, did expressed concern that its benefits are very unevenly shared and its costs unfairly distributed, and that, developing countries face difficulties in responding to the central challenge. ${ }^{11}$ The demand for the establishment of NIEO remain a crucial issue for the NAM countries. At the XIII summit conference in Kuala Lumpur, the movements remained deeply concerned over the continued marginalization of the developing 
countries from the benefits of globalization, and persistent income and economic gaps between the developed and developing countries. ${ }^{12}$

The NAM has not been a static movement with a static set of issues and priorities. After its conceptual baptism at Bandung (1955) and Brione (1956) and its formal launch at its first summit at Belgrade in 1961, it has travelled a long and meandering path. During this course, it has made strategic shifts in its priorities necessitated by the changing world scenario and the interests of the non- aligned world therein. Thus, in its first phase, the movement was primarily concerned with extending political and moral support to national liberation struggles taking place in a large number of countries in Asia, Africa and Latin America against colonialism and its various forms and manifestations. In its second phase, which ran co-terminus with the superpowers induced Cold War, NAM was principally concerned with charting an independent course free from the influence of the two superpowers - the US and the USSR. NAM remained a potent force throughout the period of the Cold War.

To examine this phenomenon, it is necessary to understand the concept of globalization and its impact on developing countries in general and the perception of the countries of NAM in particular. Globalization has imposed on all of as a fashionable orthodox uniformity according to which we must address such questions as budget deficits, rates of inflation interest and exchange rates, capital movements, the flexibility of labor market the affordability of social welfare systems. ${ }^{13}$ In fact non-aligned countries, due to the internal and external compulsion or requirements, are participants in the process of globalization despite the fact that they are aware that they are losers. But they are trying to strengthen themselves through conferences and gatherings under the NAM and are trying to influence the rich countries for reforms in the system.

Several internal contradictions, prevailing in the developing world, tend to weigh down the progress. Internal diversities like plurality of cultures, religions, social system, castes etc. great problems within. The idea of a new international economic order proposed by NAM seems to be an unfulfilled task. Liberalization and globalization have become the major determinants in international relations. The force of new colonialism in the form of economic and cultural colonialism are growing. Thus, there is a need for the non-aligned countries to develop and organize themselves so as to resist these forces. The Non- aligned movement being a holistic movement, has not ignored the strategic and humanitarian dimension. Strategically, the existence, production and deployment of nuclear, chemical and biological weapon is posing major threat to the security of the non-aligned countries.

The non-aligned countries are facing financial crises and the problem of debt and poverty, especially from the second half of the 1998. Stunning currency collapses in Mexico (1995), SouthEast Asia (1997), Russia (1998), and Brazil (1999) have pushed the subject to the front page. ${ }^{14}$ The non-aligned countries are using all platforms for increasing cooperation. The regional grouping among the developing countries have been striving to implement projects in different area of economic cooperation in trade, industry, joint ventures, science and technology, finance and banking, tourism etc.

Economic globalization has become an effective weapon for the US and its allies to be used for establishment of economic hegemony in the Post-Soviet Union Economic order. It has shifted the 
power equations from political to economic for dominating the political aspects at the international level. In this context, the NAM countries must take united action to ensure that their demands are met, and economic stability and security maintained. The collective pressures of NAM countries can be expected to bring about a change in the attitudes of the rich nations.

The non-aligned movement is not only respectable, but even fashionable, for a newly independent country nowadays, to assume a subordinate treaty relationship with a major power is unthinkable. The charges of morality made against neutralism appear to be echoes of another age in this decade with its overwhelming sense of danger. Non alignment is no longer the unipolar policy adopted by a few malcontents not prepared to accept a cosy subordinate relationship with the powerful ones of the world. It is respectable. It is a success. ${ }^{15}$ Globalization needs supportive governments and supportive governments need domestic political support. International economic affairs depend on political backing from powerful countries and from powerful groups in those countries. ${ }^{16}$

The future of the NAM was as spectacular as its success. Despite the bipolar tension, it failed to bring the North round to its understanding of issues of development. The NAM has for long avoided issue of conflict between its own members. This may not be possible, it will, sooner or later, feel the need of evolving a mechanism of mediation and conciliation among its members in the spirit of co- operation. For the matter, the movement should forge intimate relation with regional organization like OAU, the Arab League, the OAS, the Asean and the SAARC. ${ }^{17}$

The non- aligned movement had a certain weight in the era of decolonization, but reiteration of their non aligned credential did not prevent individual nations from having close relations with major power as the US, the erstwhile Soviet Union and the UK. For all their pious declaration on global peace, the non-aligned nations have rarely shared significant convergence of interests and have even fought among themselves. ${ }^{18}$

Responding to Cold War pressures, non- alignment sought national security through noninvolvement with military alliances, suggesting a consequential disillusionment with force as an instrument of diplomacy. Increased membership has been a source of new problems and difficulties for the process of decision-making by consensus. However, NAM has been trying to adopt action-oriented programs for securing NIEO and for promoting south- south cooperation. But success in the process remains very limited. The groups of NAM try to compete with G-7, ASEAN the Commonwealth, which are similar groups of nations.

NAM should redefine its priorities in the $21^{\text {st }}$ century and NAM is relevant to protect the world from imperialism. As Joseph Nye argues that NAM is relevant to protect the world from hard power as military hegemony and soft power as cultural hegemony. NAM has come to be a global movement, at least a movement of all third world countries, which constitute $2 / 3^{\text {rd }}$ of the total membership of the world community against the force of neo-colonialism

The economic imperialism is perpetuated by the Brettonwood institutions-IMF, World Bank, and WTO. This triumvirate is trying to impose the West's neo-liberal agenda, which is based on twin pillar of State Compression (SC) and Market Relaxation (MR) ${ }^{19}$. In short neo-liberalism is a reaction to the paternalistic 'nanny state' and aim at rolling back its frontiers. In its place, it places trust on what the noted economist Adam Smith called the invisible land. The World Trade 
Organization (WTO) which replaced its predecessor GATT in 1995 as a rule-based body, is responsible for ushering in free trade. Despite the existence of WTO, free trade is not equal to fair trade. The countries of the North advocate liberalization of trade, investment and services.

In the final analysis the new global order is one of the new alignments. The ability of NAM to realign itself within this new order will determine the success with which it is able to address issues facing the movements as well as pressing issues within the movement itself. Due to its flexibility, this movement has acquired an adaptable character. It emphasizes the establishment of the new world order based on equality, peace, security and socio- economic justice. It is opposed to the neo imperialistic trends and instruments being used by the Western Countries to dominate, by imposing their cultural values, on the socio economic and political structure of the developing countries.

\section{References}

[1] Enders, Walter and Todd Sandler. 1999. "Transnational Terrorism in the Post Cold War Era", International Studies Quarterly, vol.43, no.1, march: 145.

[2] Dhiravegin, Likhit. 1994 "The New International Parameter and the New World Order", Indian Quarterly, vol. 1, no.3, July- September: 67.

[3] Nain, S.S. 2007. Relevance of NAM in the Post Cold War Era. New Delhi: K.K. publications,

[4] Bhardwaj,Ram Dev. 1994. "New world order", third concept, vol.6, no.65, July: 26.

[5] Soedja, Tmoko. 1992. "Non Alignment and Beyond", in Varinder Grover (ed.), UNO, NAM, NIEO, SAARC and India's Foreign Policy. New Delhi : Deep and Deep Publications, 359.

[6] Gandhi, Indira. 1952. "Non- Alignment and peace" in Varinder Grover (ed.), UNO, NAM, NIEO, SAARC and India's Foreign Policy. New Delhi: Deep and Deep Publications, 359.

[7] Ibid, 349.

[8] Rajan, M.S. 1998. "Non-Alignment and the NAM", World Focus, vol. 19, no. 8, August : 11.

[9] Chhabra, Hari Sharan. 1998. "India and the NAM" World Focus, vol. 19, no. 10-11-12, NovemberDecember: 31-33.

[10] Bahadur, Kalim, 2004. "Indian Foreign Policy in a Changing World". World Focus, vol. 25, No.1011-12, October-December, 3-6.

[11] Malhotra, Inder. 1997. "Indian Foreign Policy". World Focus, vol.18, no.9, September 3-4.

[12] "Economic Issues, Final Document of the XIII Conference of Heads of State or Government of the Non-Aligned Movement Kuala-Lumpur", 24-25 February 2003, access from www. NAM Gov. za.

[13] "Address of President 1998 Nelson Mandela at the NAM Inaugural Session (25 September 1998)", Indian africanist, vol.1, no. 3-4, July- December; 33

[14] Blinder, Alan S. 1999. "Eight Steps to a Financial Order" Foreign Affaires, vol. 78, no.5, September - October: 50.

[15] Damodaran, A.K. 1992. "Jawahar Lal Nehru and Non- Alignment' in Varinder Grover (ed.), UNO, NAM, NIEO, SAARC, and India's Foreign Policy. New Delhi: Deep and Deep Publications, 174.

[16] Freden, Jeffry A. 2006. Global Capitalism: Its Fall and Rise in Twentieth Century. New York: W.W. Norton and company, 17.

[17] Quraishi, Zaheer M. 1994. 'Relevance of Non- Alignment”, India Quarterly, vol. L, nos. 1\&2, January - June: 18.

[18] Mitra, Subrata K. 2009. Nuclear, Engaged, and Non- Aligned: Contradiction and Coherence in India's Foreign Policy, India quarterly, vol. LXV, no.1, January - March: 21.

[19] Press Conference by Prime Minister Dr. Manmohan Singh at Jakarta, 23 April 2005. Accessed in 2005 at http:// Mahindra - nic.in/ press briefing/2005/04/23mi01.htm.

*Corresponding author.

E-mail address: sehgal.sheveta@ yahoo.com 